\title{
Pulsatile LH-RH Administration Induces Puberty in Hypogonadotropic GH-Deficient Patients
}

\author{
Noritaka IWATANI, Minoko KODAMA, and Teruhisa MIIKE \\ Department of Child Development, Kumamoto University School \\ of Medicine, Kumamoto 860, Japan
}

\begin{abstract}
Three growth hormone $(\mathrm{GH})$ deficient males with hypogonadotropic hypogonadism were treated with pulsatile luteinizing hormone-releasing hormone (LH-RH) administration. In two of them, the GH deficiency was idiopathic, but in the other it was secondary, caused by suprasellar germinoma. In response to LH-RH therapy, the serum testosterone (T), testicular volume, and body height increased in all three patients, and normal serum $\mathrm{T}$ levels and spermatogenesis were achieved in two patients. Gonadotropin responses to an $\mathrm{LH}-\mathrm{RH}$ test preceding therapy did not seem to be an accurate predictor of the success of LH-RH therapy. We conclude that GH-deficient patients with hypogonadotropic hypogonadism can be expected to achieve normal pubertal development and spermatogenesis with pulsatile LH-RH administration.
\end{abstract}

Key words: GH deficiency, Hypogonadotropic hypogonadism, Pulsatile LH-RH therapy.

(Endocrine Journal 40: 191-196, 1993)

LH-RH therapy has been tried for the treatment of hypothalamic hypogonadism, and many studies show that LH-RH, administered subcutaneously with a pulsatile infusion pump, successfully stimulates puberty and normal spermatogenesis. Most of the studies, however, are about patients with isolated hypogonadotropic hypogonadism (IHH) and delayed puberty [1-9]. Idiopathic or secondary GH deficient children often also have other pituitary hormone disorders [10-13]. Although for $\mathrm{GH}$-deficient patients with hypogonadotropic hypogonadism it is necessary to add therapy for hypogonadism to human $\mathrm{GH}(\mathrm{hGH})$ therapy, the timing of this therapy is crucial when they reach adolescence [14]. So far as we know, there are very few reports on the precise procedure for treating hypogonadic GH-deficient children with LH-RH therapy [15]. The aim of this study is to demonstrate the clinical efficacy of long-term pulsatile

Received July 20, 1992

Accepted: February 4, 1993

Correspondence to: Dr. Noritaka IWATANI, Department of Child Development, Kumamoto University School of Medicine, 1-1-1 Honjo, Kumamoto 860, Japan
LH-RH therapy for pubertal development and spermatogenesis in GH-deficient patients associated with hypogonadotropic hypogonadism.

\section{Subjects and Methods}

Subjects

Three males with hypogonadotropic GHdeficiency participated in the study after informed consent. The diagnosis of GH deficiency was made on the basis of $\mathrm{GH}$ response to provocation tests, insulin induced hypoglycemia, the arginine infusion test and growth hormone releasing factor (GRF) test (Table 1). Patients 1 and 2, with idiopathic GH deficiency, had been treated with $\mathrm{hGH}$ and thyroxine $\left(\mathrm{T}_{4}\right)$ from 9 and 5 years of age, respectively. Patient 3 , diagnosed with suprasellar germinoma at 13.8 years old, had impairments of $\mathrm{GH}$, thyroid stimulating hormone (TSH), and antidiuretic hormone (ADH); he had been treated with hGH, $\mathrm{T}_{4}$, and DDAVP (desmopressin acetate) after radiation therapy. All were older than 18 
Table 1. Profiles of patients at the start of $\mathrm{LH}-\mathrm{RH}$ therapy

\begin{tabular}{|c|c|c|c|c|c|c|c|c|c|c|c|}
\hline Pt & Age (yr) & $\begin{array}{l}\mathrm{Dx}^{\mathrm{a}} \\
\text { (age) }\end{array}$ & $\begin{array}{l}\text { Deficient } \\
\text { hormones }^{b}\end{array}$ & $\frac{\text { Peak }}{\text { Ins }}$ & $\frac{\text { GH (n }}{\text { Arg }}$ & $\frac{\mathrm{g} / \mathrm{m} l)^{\mathrm{c}}}{\mathrm{GRF}}$ & $\mathrm{BA}(\mathrm{yr})$ & $\begin{array}{l}\mathrm{Ht}(\mathrm{cm}) \\
\mathrm{Wt}(\mathrm{kg})\end{array}$ & $\begin{array}{l}\frac{\text { Puberty }}{\text { PH }} \\
\text { TV }(\mathrm{m} l)\end{array}$ & $\frac{\text { hCG test }^{\mathrm{d}}}{\text { Before }}$ & $\begin{array}{l}\text { Therapy } \\
\text { Previous } \\
\text { Present }^{\mathrm{e}}\end{array}$ \\
\hline 1 & 18.6 & $\begin{array}{l}\text { IGHD } \\
(9)\end{array}$ & $\mathrm{GH}, \mathrm{TSH}$ & 1.3 & & 5.3 & 14.0 & $\begin{array}{r}156.3 \\
57.8\end{array}$ & $\begin{array}{r}\text { II } \\
2\end{array}$ & $\begin{array}{r}43 \\
323\end{array}$ & $\begin{array}{l}\mathrm{GH}, \mathrm{T}_{4}, \mathrm{hCG} \\
\mathrm{GH}, \mathrm{T}_{4}\end{array}$ \\
\hline 2 & 19.2 & $\begin{array}{l}\text { IGHD } \\
(5)\end{array}$ & GH, TSH & 1.4 & 2.2 & 2.6 & 15.3 & $\begin{array}{r}169.5 \\
72.8\end{array}$ & $\begin{array}{r}\text { II } \\
2\end{array}$ & $\begin{array}{r}35 \\
425\end{array}$ & $\begin{array}{l}\mathrm{GH}, \mathrm{T}_{4}, \mathrm{~T} \\
\mathrm{~T}_{4}\end{array}$ \\
\hline 3 & 18.2 & $\begin{array}{l}\text { SGHD } \\
(13)\end{array}$ & $\mathrm{GH}, \mathrm{TSH}, \mathrm{ADH}$ & 2.1 & 3.6 & 9.0 & 14.5 & $\begin{array}{r}165.0 \\
52.0\end{array}$ & $\begin{array}{r}\text { II } \\
2\end{array}$ & ND & $\begin{array}{l}\text { GH, } T_{4}, \text { DDAVP } \\
T_{4}, \text { DDAVP, } T\end{array}$ \\
\hline
\end{tabular}

BA, bone age; PH, pubic hair according to Tanner score; TV, testicular volume; IGHD, idiopathic GH deficiency; SGHD,

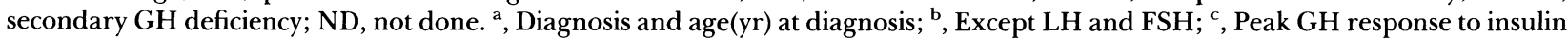
(Ins), arginine (Arg), and GRF; ${ }^{\mathrm{d}}$, Serum T concentration (ng/d $l$ ) before and after hCG test; ${ }^{\mathrm{e}}$, Substitution therapy at the start of and during LH-RH therapy.

years at the start of LH-RH treatment (Table 1). The diagnoses of hypogonadotropic hypogonadism were established from the results of pubertal signs, basal serum levels of gonadotropins and T, and gonadotropin responses to a bolus LH-RH test.

\section{Methods}

For the bolus LH-RH test, an intravenous injection of $100 \mu \mathrm{g} \mathrm{LH}-\mathrm{RH}$ (Tanabe Pharm. Ltd., Osaka, Japan) was given, and blood samples were drawn for $\mathrm{LH}$ and FSH estimations before and at 15, 30, 60, 90 and $120 \mathrm{~min}$ thereafter. Preceding LH-RH therapy, the bolus LH-RH tests were performed before and after seven consecutive days' administration of $100 \mu \mathrm{g}$ of $\mathrm{LH}-\mathrm{RH} /$ day (consecutive stimulation test). LH and FSH responses to the LH-RH test were estimated with regard to the area under the curve (AUC) above the level $t=0$. The human chorionic gonadotropin (hCG) test was performed to reveal the responsiveness of Leydig cells to the injection of hCG (Pregnyl, Organon) intramuscularly, 5000 U/day for three consecutive days. Blood samples were drawn daily on the first to fourth day of the test. Testicular volume was measured with a Prader's orchidometer. Bone age was estimated by the Tanner-Whitehouse II method. Prediction of adult height was calculated by a method of Tanner et al. but age in the equation was adapted bone age instead of chronological age [16].

Serum hormones were determined in duplicate by standard radioimmunologic methods (RIA): Serum LH and FSH were measured by a solid phase method (SPAC-S LH and SPAC-S FSH kits, Daiichi Radioisotope Inst., Japan); serum $T$ was measured with a DPC total-testosterone kit (Diagnostic Products Corp.) at the SMI Bristol Laboratory, Tokyo, Japan. The serum samples were stored at $-20^{\circ} \mathrm{C}$ until assayed.

\section{Study protocol}

The LH-RH used for therapy was "Hypocrine" containing 400 or $800 \mu \mathrm{g} \mathrm{LH}-\mathrm{RH} / \mathrm{ml}$ (Tanabe Pharm. Ltd., Osaka, Japan). It was administered with a computerized portable pulsatile infusion pump (SP-3I, Nipro Corp., Tokyo, Japan). Throughout the treatment period, the hormone was injected at $120 \mathrm{~min}$ intervals for $24 \mathrm{~h}$ via a subcutaneous cannula inserted into the anterior abdominal wall.

The starting pulse dose of $10 \mu \mathrm{g}$ was increased as necessary if there was no change in the serum $\mathrm{T}$ level. During treatment, a bolus LH-RH test and serum $\mathrm{T}$ measurement were performed at appropriate intervals.

\section{Results}

\section{Pretreatment}

Gonadotropin responses to the bolus LH-RH test were subnormal for age in all patients. After the LH-RH consecutive stimulation test, these responses were apparently improved in Patient 1 but only slightly improved in the other two (Fig. 1).

The hCG test revealed a positive Leydig cell 
reaction with serum T level elevation in Patients 1 and 2 at the start of LH-RH therapy (Table 1). Since Patient 3's testicular volume was already $4 \mathrm{ml}$ and his public hair Tanner score was II at the onset of germinoma (13.8 years old), the hCG test for Leydig cell function was not performed. These

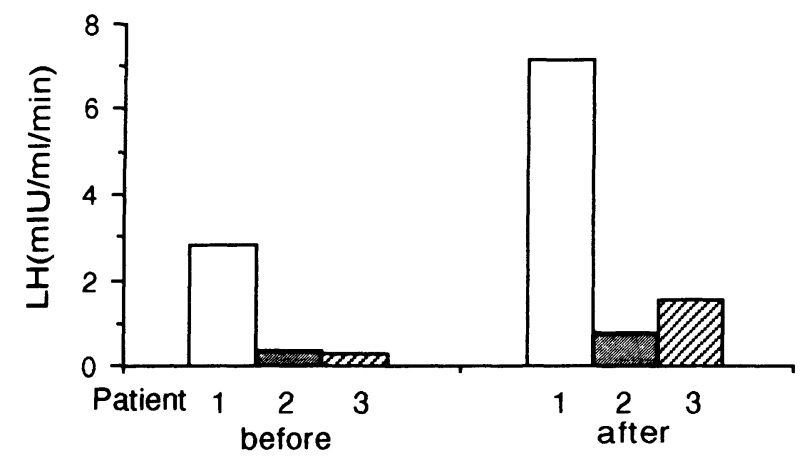

Fig. 1. LH response to bolus LH-RH tests before and after seven consecutive days' administration of $100 \mu \mathrm{g}$ of LH-RH/day. LH response was estimated with regard to the area under the curve (AUC) for $120 \mathrm{~min}$ above the level $\mathbf{t}=0$. findings indicated that all patients had sufficient gonadal function potency to respond to the gonadotropins.

\section{Treatment outcomes}

Patients 1 to 3 were treated with LH-RH for 32 , 13 , and 34 months, respectively, but Patient 1 also received hGH treatment simultaneously. A bolus $100 \mu \mathrm{g}$ LH-RH test during therapy showed improved gonadotropin responses, but these improvements remained small in all patients (Table 2).

In Patient 1 , serum $\mathrm{T}$ concentrations increased to $366 \mathrm{ng} / \mathrm{d} l$ during $10 \mu \mathrm{g} /$ pulse LH-RH administration, but then returned to the prepubertal level even after a double dosage because of intermittent use of the infusion pump. We again motivated the patient to continue therapy properly, and increased the LH-RH dosage to $40 \mu \mathrm{g} /$ pulse. After that, the serum $\mathrm{T}$ increased to a normal adult level, and by the end of therapy the $\mathrm{T}$ level was

Table 2. Clinical course of patients during LH-RH therapy

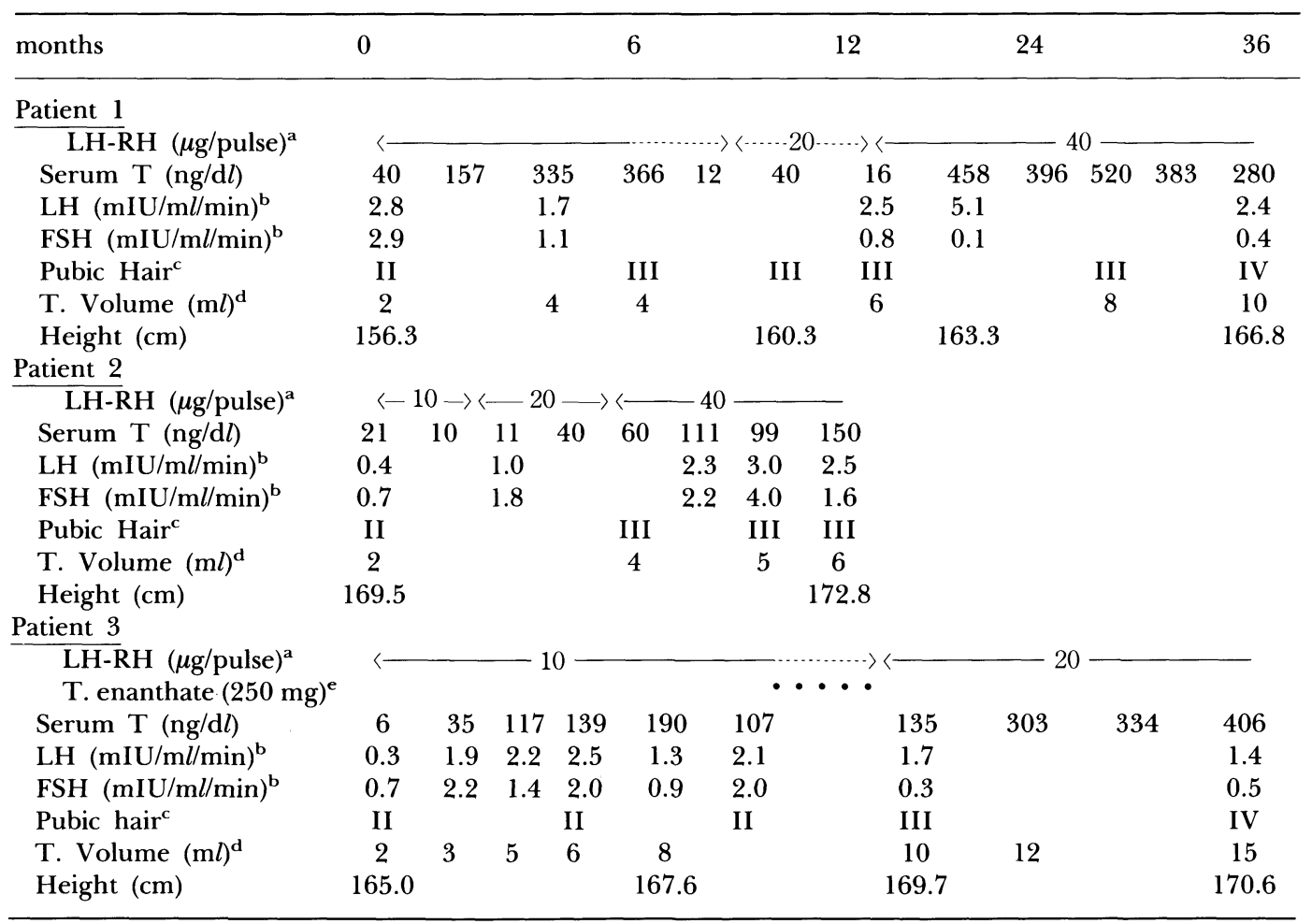

a, Dotted line indicates period of intermittent use of infusion pump; ${ }^{b}$, Values are the area under the curve (AUC) after LH-RH test; ${ }^{c}$, Tanner score; ${ }^{d}$, Testicular volume of one side; ${ }^{\mathrm{e}}$, Testosterone enanthate injected at the dotted times. Normal range: serum $T$ in adulthood, 250-1100 ng/d $l$; AUC of LH and FSH, $11.9 \pm 3.3$ and $4.7 \pm 2.2 \mathrm{mIU} / \mathrm{ml} / \mathrm{min}$, respectively, at Tanner score II (mean $\pm \mathrm{SD}, \mathrm{n}=5$ ). 
keeping within the low normal range. His clinical pubertal signs developed as follows: pubic hair developed from Tanner score II to IV, testicular volume from $2 \mathrm{ml}$ to $10 \mathrm{ml}$, and voice break occurred. Height gain during therapy was $10.5 \mathrm{~cm}$ in 32 months (Table 2), and bone age developed from 14.0 to 16.5 years old. Predicted adult height at the end of this study was $170 \mathrm{~cm}$.

In Patient 2, the LH-RH dosage was increased stepwise to $40 \mu \mathrm{g} /$ pulse within four months. Although the serum $\mathrm{T}$ concentration increased dose-dependently in response to $\mathrm{LH}-\mathrm{RH}$ treatment, the level did not reach the normal range. His pubertal development reached a Tanner score III for pubic hair and a maximum $6 \mathrm{~m} l$ testicular volume at 13 months after starting LH-RH treatment. Height gain was $3.3 \mathrm{~cm}$ in 13 months (Table 2 ), and bone age developed from 15.3 to 15.5 years old. Predicted adult height at the end of this study was $178 \mathrm{~cm}$. After the 13 months, he did not carry through completely with the therapy because of his college activities.

In Patient 3, the LH-RH dosage continued with $10 \mu \mathrm{g} /$ pulse for 12 months, but serum $\mathrm{T}$ increases were slow and remained subnormal. For the following six months, he used the infusion pump only at night because it interfered with his student activities. Since his final height was predicted to exceed the standard, testosterone administration (testosterone enanthate $250 \mathrm{mg}$ intramuscularly, once a month for 5 months) was added to the therapy to accelerate bone age maturation. We encouraged him again to carry through with the therapy and increased the LH-RH dosage to 20 $\mu \mathrm{g} /$ pulse (Table 2). At the latest measurement, the serum $\mathrm{T}$ concentration had increased to $406 \mathrm{ng} / \mathrm{d} l$. His pubic hair reached Tanner score IV and testicular volume reached $15 \mathrm{ml}$. Height gain during therapy was $5.1 \mathrm{~cm}$ in 34 months (Table 2), and bone age developed from 14.5 to 17.0 years old. Predicted adult height at the end of this study was $174 \mathrm{~cm}$.

All patients noted an increase in the frequency of spontaneous erections. The sperm counts of Patients 1 and 3 at the end of LH-RH treatment were $86 \mathrm{million} / \mathrm{ml}$ spermatozoa with $50 \%$ motility and $152 \mathrm{million} / \mathrm{ml}$ spermatozoa with $65 \%$ motility, respectively, enough to be fertile. Patient 2 could not provide a semen sample. Serum thyroid hormone levels of the three were within the normal range throughout treatment. No side effects relating to the LH-RH therapy were observed in any of the patients.

\section{Discussion}

The goal of LH-RH treatment in patients suffering from hypogonadotropic hypogonadism should be not only virilization but also fertility. Pulsatile administration of LH-RH by means of a small portable pump seems to be the most physiological way of achieving pubertal development and spermatogenesis [17]. The efficacy of the treatment, however, is still unknown in patients with GH deficiency. Our three hypogonadotropic hypogonadism patients were associated with GH deficiency and pubertal induction was achieved by long-term therapy.

It is generally considered that the LH-RH consecutive stimulation test is useful for determining whether a lesion is on the hypothalamus or the pituitary, and that LH-RH therapy is effective for patients with a hypothalamic lesion. Patient 1, whose gonadotropin responses to the LH-RH consecutive stimulation test were the best of the three patients, showed excellent responses to LH-RH therapy in pubertal development, $\mathrm{T}$ increase, and spermatogenesis. Patient 3, whose gonadotropin responses were poor, also showed increases in serum $\mathrm{T}$, testicular volume, and spermatozoa up to a normal adult level during long-term administration of LH-RH. Even in Patient 2, carrying through the administration of LH-RH for a much longer term may lead to success, although his gonadotropin responses were also poor. These results indicate that the LH-RH test does not necessarily predict the success of LH-RH therapy, and that long-term stimulation of LH-RH can be effective in achieving normal pubertal induction even in severe hypothalamicpituitary dysfunction [7].

Further, GH may contribute to the gonadal response to LH-RH therapy. It is well known that isolated GH-deficient children have delayed puberty [18] and that treatment of these patients with human GH induces sexual maturation [19]. These clinical observations suggest that GH and/or IGF-I has a stimulatory effect on gonadal function [20]. The existence of GH and IGF-I receptors on the testes (Leydig cells and Sertoli cells) also indicates the possibility of $\mathrm{GH}$ contribution to 
gonadal function [21-24]. In Patient 1, GH administration might have collaborated with LH-RH treatment in promoting testicular function, resulting in good responses in serum $\mathrm{T}$ increase and spermatogenesis. Further investigation is needed to find out whether or not $\mathrm{GH}$ administration together with LH-RH therapy promotes gonadal activation and brings about better results in $T$ response and spermatogenesis.

It is generally considered that the treatment should be started as late as possible so that final height may be maximized. If the treatment is started too late, however, overgrowth may result from a delay in bone maturation, and a sexual inferiority complex may arise. On the other hand, if treatment is started too early, final height may be lower than expected.

In this study, we started LH-RH administration at a bone age of approximately 14-15 years old, and somatic growth gain was observed in all three patients during treatment. The growth gain of Patient 1, who was also treated with hGH, was better than that of the other patients, and his predicted adult height was approximately $170 \mathrm{~cm}$, the mean standard adult height. In Patient 3 , since his final height was predicted to exceed the standard, we administered testosterone enanthate during the period of his intermittent use of the infusion pump in order to accelerate bone age maturation; at the end of this study his height reached $170.6 \mathrm{~cm}$, nearly his final height. Patient 2 is still growing and is expected to exceed standard adult height. To prevent overgrowth, the therapy for such patients should not be started too late.

We conclude that it is possible for GH-deficient patients with hypogonadotropic hypogonadism to achieve normal pubertal development and spermatogenesis through long-term pulsatile LH-RH therapy, and that the patients can be expected to have height gain during the therapy.

\section{References}

1. Valk TW, Corley KP, Kelch Rp, Marshall JC (1980) Hypogonadotropic hypogonadism: Hormonal responses to low dose pulsatile administration of gonadotropin-releasing hormone. J Clin Endocrinol Metab 51: 730-738.

2. Skalin GS, Nillius SJ, Wibell L, Wide L (1982) Chronic pulsatile low dose GnRH therapy for induction of testosterone production and spermatogenesis in a man with secondary hypogonadotropic hypogonadism. J Clin Endocrinol Metab 55: 723-726.

3. Hoffman AR, Crowley Jr WF (1982) Induction of puberty in men by long-term pulsatile adminsitration of low-dose gonadotropin-releasing hormone. $N$ Engl J Med 307: 1237-1241.

4. Shargil AA (1987) Treatment of idiopathic hypogonadotropic hypogonadism in men with luteinizing hormone-releasing hormone: a comparison of treatment with daily injections and with the pulsatile infusion pump. Fertil Steril 47: 492-501.

5. Aulitzky W, Frick J, Galvan G (1988) Pulsatile luteinizing hormone-releasing hormone treatment of male hypogonadotropic hypogonadism. Fertil Steril 50: 480-486.

6. Liu L, Banks SM, Barnes KM, Sherins RJ (1988) Two-year comparison of testicular responses to pulsatile gonadotropin-releasing hormone and exogenous gonadotropins from the inception of therapy in men with isolated hypogonadotropic hypogonadism. $J$ Clin Endocrinol Metab 67: 1140-1145.
7. Crowley Jr WF, Whitcomb RW (1990) Gonadotropin-releasing hormone deficiency in men: Diagnosis and treatment with exogenous gonadotropin-releasing hormone. Am J Obstet Gynecol 163: 1572-1758.

8. Whitcomb RW, Crowley Jr WF (1990) Clinical review 4: Diagnosis and treatment of isolated gonadotropin-releasing hormone deficiency in men. J Clin Endocrinol Metab 70: 3-7.

9. Giusti M, Cavagnaro P, Torre R (1991) Role of pulsatile luteinizing-releasing hormone therapy in males with idiopathic hypogonadotropic hypogonadism and delayed puberty. Recenti Prog Med 82: 48-53.

10. Burns EC, Tanner JM, Preece MA, Cameron N (1981) Final height and pubertal development in 55 children with idiopathic growth hormone deficiency, treated for between 2 and 15 years with human growth hormone. Eur J Pediatr 137: 155-164.

11. Bourguignon JP, Vanderschueren-Lodeweyckx M, Wolter R, Malvaux P, Craen M, LDuCaju MVL, Ernould C, Franchimont P (1982) Hypopituitarism and idiopathic delayed puberty: a longitudinal study in an attempt to diagnose gonadotropin deficiency before puberty. J Clin Endocrinol Metab 54: 733-744.

12. Joss E, Zuppinger K, Schwarz HP, Roten H (1983) Final height of patients with pituitary growth failure and changes in growth variables after long term hormonal therapy. Pediatr Res 17: 676-679. 
13. Martínez AS, Heinrich JJ, Rivarola MA, Bergadá (1986) Pubertal development in male hypopituitarism. Eur J Pediatr 145: 384-388.

14. Okada Y, Kondo T, Okamato S, Ogawa M (1992) Induction of ovulation and spermatogenesis by hMG/hCG in hypogonadotropic GH-deficient patients. Endocrinol Japon 39: 31-43.

15. Hosoda A, Fujieda K, Matsuura K, Nakagawa K (1988) An experience in therapy for central hypogonadism by administration small dose of GnRH pulsatile. Adolescentology 6: 367-373 (In Japanese).

16. Tanner JM, Whitehouse RH, Marshall WA, Carter BS (1975) Prediction of adult height from height, bone age, and occurrence of menarche, at ages 4 to 16 with allowance for midparent height. Arch Dis Child 50: 14-26.

17. Wu FCW, Butler GE, Kelnar CJH, Stirling HF, Huhtaniemi I (1991) Patterns of pulsatile luteinizing hormone and follicle-stimulating hormone secretion in prepubertal (midchildhood) boys and girls and patients with idiopathic hypogonadotropic hypogonadism (Kallman's syndrome): a study using an ultrasensitive time-resolved immunofluorometric assay. J Clin Endocrinol Metab 72: 1229-1237.

18. Price DA, Shalet SM, Clayton PE (1988) Management of idiopathic growth hormone deficient patients during puberty. Acta Paediatr Scand 347:
44-51.

19. Tanner JM, Whitehouse RH (1975) A note on the bone age at which patients with true isolated growth hormone deficiency enter puberty. J Clin Endocrinol Metab 41: 788-790.

20. Kulin HE, Samojlik E, Santen R, Santner S (1981) The effect of growth hormone on the Leydig cell response to chronic gonadotrophin in boys with hypopituitarism. Clin Endocrinol 15: 463-472.

21. DeMellow JSM, Handelsman DJ, Baxter R (1987) Short-term exposure to insulin-like growth factors stimulates testosterone production by testicular interstitial cells. Acta Endocrinol (Copenh) 115: 483-489.

22. Horikawa R, Asakawa K, Hizuka N, Takano K, Shizume K (1989) Growth hormone and insulinlike growth factor I stimulate Leydig cell steroidogenesis. Euro J Pharm 166: 87-94.

23. Haskell TLJ, Vison N, Terracio L (1986) Characterization of insulin and insulin-like growth factor I receptors of purified Leydig cells and their role in steroidogenesis in primary culture: A comparative study. Endocrinology 119: 1641-1647.

24. Smith EP, Svoboda ME, VanWyk JJ, Kierszenbaum AL, Tres LL (1987) Partial characterization of a somatomedin-like peptide from the medium of cultured rat Sertoli cells. Endocrinology 120: 186-193. 